\title{
Topical cutaneous application of carbon dioxide via a hydrogel for improved fracture repair: results of phase I clinical safety trial
}

Takahiro Niikura ${ }^{1 *}$ (D) Takashi Iwakura ${ }^{2}$, Takashi Omori ${ }^{3}$, Sang Yang Lee ${ }^{4}$, Yoshitada Sakai ${ }^{5}$, Toshihiro Akisue ${ }^{6}$, Keisuke Oe ${ }^{1}$, Tomoaki Fukui ${ }^{1}$, Takehiko Matsushita', Tomoyuki Matsumoto ${ }^{1}$ and Ryosuke Kuroda ${ }^{1}$

\begin{abstract}
Background: Clinicians have very limited options to improve fracture repair. Therefore, it is critical to develop a new clinically available therapeutic option to assist fracture repair biologically. We previously reported that the topical cutaneous application of carbon dioxide $\left(\mathrm{CO}_{2}\right)$ via a $\mathrm{CO}_{2}$ absorption-enhancing hydrogel accelerates fracture repair in rats by increasing blood flow and angiogenesis and promoting endochondral ossification. The aim of this study was to assess the safety and efficacy of $\mathrm{CO}_{2}$ therapy in patients with fractures.

Methods: Patients with fractures of the femur and tibia were prospectively enrolled into this study with ethical approval and informed consent. The $\mathrm{CO}_{2}$ absorption-enhancing hydrogel was applied to the fractured lower limbs of patients, and then $100 \% \mathrm{CO}_{2}$ was administered daily into a sealed space for 20 min over 4 weeks postoperatively. Safety was assessed based on vital signs, blood parameters, adverse events, and arterial and expired gas analyses. As the efficacy outcome, blood flow at the level of the fracture site and at a site $5 \mathrm{~cm}$ from the fracture in the affected limb was measured using a laser Doppler blood flow meter.

Results: Nineteen patients were subjected to complete analysis. No adverse events were observed. Arterial and expired gas analyses revealed no adverse systemic effects including hypercapnia. The mean ratio of blood flow $20 \mathrm{~min}$ after $\mathrm{CO}_{2}$ therapy compared with the pre-treatment level increased by approximately 2 -fold in a time-dependent manner.
\end{abstract}

Conclusions: The findings of the present study revealed that $\mathrm{CO}_{2}$ therapy is safe to apply to human patients and that it can enhance blood flow in the fractured limbs.

Trial registration: This study has been registered in the UMIN Clinical Trials Registry (Registration number: UMIN000013641, Date of registration: July 1, 2014).

Keywords: Bone, Fracture repair, Carbon dioxide, Blood flow, Clinical trial

\footnotetext{
* Correspondence: tniikura@med.kobe-u.ac.jp

${ }^{1}$ Department of Orthopaedic Surgery, Kobe University Graduate School of

Medicine, 7-5-1 Kusunoki-cho, Chuo-ku, Kobe 650-0017, Japan

Full list of author information is available at the end of the article
}

(c) The Author(s). 2019 Open Access This article is distributed under the terms of the Creative Commons Attribution 4.0 International License (http://creativecommons.org/licenses/by/4.0/) which permits unrestricted use, distribution, and reproduction in any medium, provided you give appropriate credit to the original author(s) and the source, provide a link to the Creative Commons license, and indicate if changes were made. The Creative Commons Public Domain Dedication waiver (http://creativecommons.org/publicdomain/zero/1.0/) applies to the data made available in this article, unless otherwise stated. 


\section{Background}

Clinicians have very limited options to biologically improve fracture repair. Although there are a few treatment options such as bone morphogenetic proteins [1-6], low-intensity pulsed ultrasound [7-9], and a pulsed electromagnetic field [10-12], which are used in clinical practice, a search of the existing literature indicated that the effectiveness of these treatments is limited [13-24]. Therefore, it is critical to develop a new clinically available therapeutic option to assist fracture repair biologically.

We previously reported that the topical cutaneous application of carbon dioxide $\left(\mathrm{CO}_{2}\right)$ by means of a $\mathrm{CO}_{2}$ absorption-enhancing hydrogel accelerates fracture repair in rats by increasing blood flow and angiogenesis and by promoting endochondral ossification [25]. This $\mathrm{CO}_{2}$ therapy induces vasodilation by changing the $\mathrm{pH}$ of blood, and it has an immediate effect, increasing the blood flow. In contrast, $\mathrm{CO}_{2}$ therapy induces the expression of vascular endothelial growth factor and increases subsequent angiogenesis. It is thought that this therapy increases vascularity via both of these mechanisms. This $\mathrm{CO}_{2}$ therapy is thus considered a promising clinically available tool that can be used to assist fracture repair. Therefore, based on the efficacy observed in a pre-clinical study, we conducted a clinical trial involving human subjects. We previously applied the $\mathrm{CO}_{2}$ therapy for the treatment of healthy volunteers [26] and found that it caused no adverse events. This study also indicated that $\mathrm{CO}_{2}$ therapy induced an artificial Bohr effect in vivo and facilitated the dissociation of oxygen from hemoglobin, leading to local oxygenation in the human body. The present study is the first exploratory trial of $\mathrm{CO}_{2}$ therapy involving human patients. The aims of this study were mainly to assess the safety of the technique and to evaluate its efficacy when applied to patients with fractures.

\section{Methods}

Study design, ethics approval, and informed consent

This study was a prospective, open-label, single-arm, single-center trial. The study protocol was approved by the Institutional Review Board (Approved number: 260008) and the study has been registered in the UMIN Clinical Trials Registry (Registration number: UMIN000013641, Date of registration: July 1, 2014). Prior to the study, we obtained written informed consent from patients who were eligible.

\section{Inclusion criteria}

Patients who fulfilled the following criteria were included in this study: fractures of the lower extremities; either fresh fracture or nonunion; either femur fracture or tibia fracture; within 2 weeks of surgery; aged 15 years and older; provided written informed consent.

\section{Exclusion criteria}

Patients with any of the following were excluded: pathological fractures; dermatologic disease in the fractured limb; active infection in the fractured limb; active bleeding postoperatively; use of any techniques to assist fracture repair such as low-intensity pulsed ultrasound.

\section{Sample size}

We included 20 patients; however, this was not based on any statistical power calculation, as it was difficult to obtain sufficient relevant information to perform the necessary calculations for a preliminary and exploratory study.

\section{$\mathrm{CO}_{2}$ therapy}

The $\mathrm{CO}_{2}$ absorption-enhancing hydrogel ${ }^{26}$ (NeoChemir, Kobe, Japan) was applied to the skin where we intended to perform trans-cutaneous $\mathrm{CO}_{2}$ absorption, that is, the fractured lower extremity of the patients. A polyethylene bag, which can seal the body surface and retain the gas within, was attached to the limb and sealed, and then $100 \% \mathrm{CO}_{2}$ gas was administered into the bag for $20 \mathrm{~min}$. This treatment was applied to the entire limb, that is, the lower extremity from the hip joint to the toes.

$\mathrm{CO}_{2}$ therapy was performed daily for $20 \mathrm{~min} /$ day over a 4-week period during hospitalization. We set the treatment period as 4 weeks by considering the duration of hospitalization. The main purpose of this early phase clinical trial was to demonstrate the safety of $\mathrm{CO}_{2}$ therapy in human patients for the first time. We considered that therapy safety assessments would be more favorable when performed during hospitalization than in the outpatient clinic. The criteria adopted for the initiation of $\mathrm{CO}_{2}$ therapy were no active bleeding, no signs of surgical site infection, and stable general condition after surgery for fresh fractures or nonunion of the lower limb.

\section{Vital signs}

Blood pressure, pulse, body temperature, and $\mathrm{SpO}_{2}$ were measured before and after each session of $\mathrm{CO}_{2}$ therapy.

\section{Blood examination}

Routine blood examination was performed before and after surgery. Clinically significant values were checked by physicians to diagnose any possible systemic side effects of the $\mathrm{CO}_{2}$ therapy.

\section{Arterial gas analysis}

Arterial gas analysis was performed immediately before and after $\mathrm{CO}_{2}$ therapy on day 14 after the initiation of 
treatment. Arterial blood was collected from the femoral artery.

\section{Expired gas analysis}

Expired gas analysis was performed before and during $\mathrm{CO}_{2}$ therapy on day 14 after the initiation of treatment using a Cpex-1 ventilatory expired gas analysis system (NIHON MEDIX CO., LTD., Chiba, Japan).

\section{Adverse events}

Physicians monitored the patients daily for any adverse events including systemic and local events during the 4week treatment period and at each outpatient clinic visit following discharge from the hospital.

\section{Measurement of blood flow in the patients' limbs}

Blood flow in the patients' limbs, both in the fractured limb and the contra-lateral healthy limb, was measured using a laser Doppler blood flow meter (Cyber Med CDF2000; Nexis, Fukuoka, Japan). Blood flow was also measured at the level of the fracture site and at a point $5 \mathrm{~cm}$ from the fracture site in both limbs. Blood flow was measured continuously from before the commencement of $\mathrm{CO}_{2}$ therapy to $20 \mathrm{~min}$ after the 20 -min period of $\mathrm{CO}_{2}$ therapy. These blood flow measurements were obtained on three separate days, specifically the first day of $\mathrm{CO}_{2}$ therapy and on days 14 and 28 after the initiation of $\mathrm{CO}_{2}$ therapy.

\section{Follow-up}

After discharge from the hospital, the patients were followed-up routinely in an outpatient clinic. The follow-up period was defined as the time from the first day of $\mathrm{CO}_{2}$ therapy to the most recent outpatient visit.

\section{Radiographic and clinical fracture union assessment}

Radiographic and clinical fracture unions were assessed during the routine follow-ups in the outpatient clinic after discharge from the hospital. Completion of bony bridging at three of the four cortices for diaphyseal fractures and disappearance of the fracture line for epiphyseal and metaphyseal fractures were judged as radiographic fracture union. Clinical fracture union was assumed when a patient was able to bear full weight on the affected limb without pain.

\section{Statistics}

Each patient was assigned an identification number, and all information was maintained confidential. The investigator filled out the data for each patient in a case report form, which was transferred to a data manager. The dataset compiled after data cleaning by the data manager was transferred to a biostatistician who performed the appropriate statistical analyses.
The patients' baseline characteristics were summarized as summary statistics (number of patients, mean, standard deviation, minimum, median, and maximum) for continuous valuables and as categorical frequency and proportion for nominal variables.

The outcomes of the arterial gas and expired gas analyses were obtained on day 14 of $\mathrm{CO}_{2}$ therapy. For each outcome, the mean values with the respective $95 \%$ confidence intervals were determined for the differences between pre-treatment and at $20 \mathrm{~min}$ after the initiation of treatment. As the endpoint of blood flow, we estimated the blood flow ratio for each patient defined as the ratio of blood flow at $20 \mathrm{~min}$ after treatment relative to that at pre-treatment. The mean, range, and 95\% confidence interval of the blood flow ratio were calculated for the endpoint, for both the measurement sites and for each of the three measurement days (days 1, 14, and 28). We calculated $p$-values for the endpoint using a Wilcoxon signed rank test with a null hypothesis that the population mean of the blood flow ratio was 1 . A small $p$-value supports the rejection of the aforementioned null hypothesis. We adopted a significance level of 0.05 and did not consider adjusting any multiplicity for the statistical test because this study constituted an exploratory examination. The additional data points were as follows: pretreatment, $5 \mathrm{~min}$ after the initiation of the $\mathrm{CO}_{2}$ therapy, $10 \mathrm{~min}$ after the initiation of the $\mathrm{CO}_{2}$ therapy, $15 \mathrm{~min}$ after the initiation of the $\mathrm{CO}_{2}$ therapy, $20 \mathrm{~min}$ after the initiation of the $\mathrm{CO}_{2}$ therapy, 5 min after the termination of the $\mathrm{CO}_{2}$ therapy, $10 \mathrm{~min}$ after the termination of the $\mathrm{CO}_{2}$ therapy, $15 \mathrm{~min}$ after the termination of the $\mathrm{CO}_{2}$ therapy, and $20 \mathrm{~min}$ after the termination of the $\mathrm{CO}_{2}$ therapy. We also calculated the blood flow ratio for each patient defined as the ratio of blood flow at each data point relative to that at pre-treatment.

Additionally, we conducted sub-group analyses to investigate the effects of age, type of osteosynthesis, time of initiation of weight bearing, affected bone (femur or tibia), and smoking on the blood flow-enhancing effects of $\mathrm{CO}_{2}$ therapy. We calculated $p$-values using the Mann-Whitney $U$ test to compare two groups and the Kruskal-Wallis test to compare three groups. All statistical analyses were performed using SAS software version 9.4 (SAS Institute, Cary, NC).

\section{Results}

\section{Patients' baseline characteristics}

Twenty patients were enrolled to the trial in accordance with the study design. The patients' baseline characteristics are summarized in Table 1. One of the patients (ID 11003) dropped out from the study on the third day after the initiation of $\mathrm{CO}_{2}$ therapy. This was because the patient expressed a wish to receive low-intensity pulsed ultrasound for fracture treatment. Therefore, all analyses 
Table 1 Patients' baseline characteristics

\begin{tabular}{|c|c|c|c|c|c|c|c|c|c|c|}
\hline Patient ID & $\begin{array}{l}\text { Age } \\
\text { range }\end{array}$ & Sex & $\mathrm{BMl}$ & $\begin{array}{l}\text { Fresh fracture or } \\
\text { Nonunion }\end{array}$ & $\begin{array}{l}\text { Affected } \\
\text { bone }\end{array}$ & $\begin{array}{l}\text { Fracture } \\
\text { level }\end{array}$ & Smoking & Comorbidities & $\begin{array}{l}\text { Days from surgery } \\
\text { to } \mathrm{CO}_{2} \text { therapy }\end{array}$ & $\begin{array}{l}\text { Follow-up } \\
\text { (months) }\end{array}$ \\
\hline 11,001 & $50-59$ & $M$ & 28.7 & Nonunion & Femur & 32 & Current & Previous infection & 9 & 48 \\
\hline 11,002 & $60-69$ & $\mathrm{~F}$ & 22.4 & Nonunion & Femur & 31 & & RA, AFF & 10 & 48 \\
\hline 11,003 & $40-49$ & M & 25.7 & Fresh fracture & Tibia & 41 & Current & & 11 & 26 \\
\hline 11,004 & $40-49$ & M & 30.1 & Fresh fracture & Tibia & 41 & Current & $\begin{array}{l}\text { Gustilo type II open } \\
\text { fracture }\end{array}$ & 10 & 24 \\
\hline 11,005 & $60-69$ & $\mathrm{~F}$ & 23.1 & Fresh fracture & Tibia & 41 & & $\begin{array}{l}\text { RA, Adult Still's } \\
\text { disease, HT, HL }\end{array}$ & 11 & 9 \\
\hline 11,006 & $20-29$ & M & 25.5 & Nonunion & Tibia & 43 & Current & & 7 & 33 \\
\hline 11,007 & $40-49$ & $\mathrm{~F}$ & 18.8 & Nonunion & Femur & $32+33$ & & & 6 & 46 \\
\hline 11,008 & $20-29$ & M & 27.3 & Nonunion & Femur & 32 & Current & & 7 & 17 \\
\hline 11,009 & $70-79$ & $\mathrm{~F}$ & 29.4 & Fresh fracture & Tibia & 33 & & Graves' disease, HT & 12 & 15 \\
\hline 11,010 & $20-29$ & M & 23.6 & Nonunion & Tibia & 42 & Current & & 9 & 31 \\
\hline 11,011 & $40-49$ & M & 27.4 & Fresh fracture & Tibia & 41 & Current & & 7 & 24 \\
\hline 11,012 & $40-49$ & M & 23.8 & Nonunion & Tibia & 43 & Current & & 9 & 42 \\
\hline 11,013 & 30-39 & M & 24.9 & Fresh fracture & Tibia & 41 & Previous & & 9 & 36 \\
\hline 11,014 & $60-69$ & M & 24.8 & Fresh fracture & Femur & 32 & Previous & $\mathrm{DM}, \mathrm{HT}$ & 12 & 14 \\
\hline 11,015 & $40-49$ & $\mathrm{~F}$ & 25.3 & Fresh fracture & Tibia & 44 & Current & $\begin{array}{l}\text { Uterus myoma, } \\
\text { Ovarian tumor }\end{array}$ & 6 & 12 \\
\hline 11,016 & $40-49$ & M & 22 & Nonunion & Tibia & 42 & Current & & 9 & 36 \\
\hline 11,017 & $50-59$ & M & 27.9 & Nonunion & Femur & 32 & Current & $\begin{array}{l}\text { Duodenum ulcer, } \\
\text { Depression }\end{array}$ & 6 & 15 \\
\hline 11,018 & $60-69$ & $\mathrm{~F}$ & 25 & Nonunion & Tibia & 32 & Current & $\mathrm{RA}, \mathrm{HT}$ & 7 & 24 \\
\hline 11,019 & $50-59$ & M & 29.2 & Nonunion & Femur & 31 & & & 2 & 24 \\
\hline 11,020 & $50-59$ & M & 26.4 & Nonunion & Femur & 32 & Current & & 2 & 25 \\
\hline
\end{tabular}

$M$ male, $F$ female, $B M I$ body mass index, $R A$ rheumatoid arthritis, $A F F$ atypical femoral fracture, $H T$ hypertension, $H L$ hyperlipidemia, $D M$ diabetes mellitus Fracture level was coded with the AO/OTA classification. AO: Arbeitsgemeinschaft für Osteosynthesefragen, OTA: Orthopaedic Trauma Association Smoking: A current smoker is a patient who smoked at the time of initiation of the treatment at the author's institute. They were advised to quit smoking in order to be treated at the author's institute. Previous smoker means a patient who quit smoking at least 1 year prior to the initiation of the treatment at the author's institute

Days from surgery to $\mathrm{CO}_{2}$ therapy: Days from surgery to initiation of the $\mathrm{CO}_{2}$ therapy

Follow-up (months): Months from initiation of the $\mathrm{CO}_{2}$ therapy to the most recent outpatient clinic visit

were conducted using the data obtained from the remaining 19 patients. Of the 19 patients for whom complete data analyses were performed, 13 were men and six were women, with a mean age of 48.7 years (range, 23-76 years) and mean body mass index of 25.6 (range, 18.8-30.1). Among the fractures treated, seven were fresh fractures and 12 were nonunions. The fractured bone was the femur in eight patients and tibia in 11 patients. The percentage of smokers among the 19 patients was $73.7 \%$ (12 current smokers and two previous smokers). The mean number of days from surgery to the initiation of $\mathrm{CO}_{2}$ therapy was 7.9 (range, 2-12), and the mean followup period was 27.5 months (range, 9-48).

\section{Vital signs}

Figure 1 shows the vital signs before and after $\mathrm{CO}_{2}$ therapy for 28 consecutive days. There were no marked changes in vital signs before and after $\mathrm{CO}_{2}$ therapy.

\section{Blood examination}

There were no marked deviations from the standard postoperative course with respect to blood examination (data not shown); there were no liver or kidney function disorders.

\section{Arterial gas analysis}

Arterial gas analysis revealed that there were no significant differences in each parameter before and after $\mathrm{CO}_{2}$ therapy (Table 2). Notably, no hypercapnia was observed.

\section{Expired gas analysis}

There were no significant differences in each parameter before and during $\mathrm{CO}_{2}$ therapy (Table 3).

\section{Adverse events}

No systemic or local adverse events were observed in any of the patients, and no skin-related reactions were 

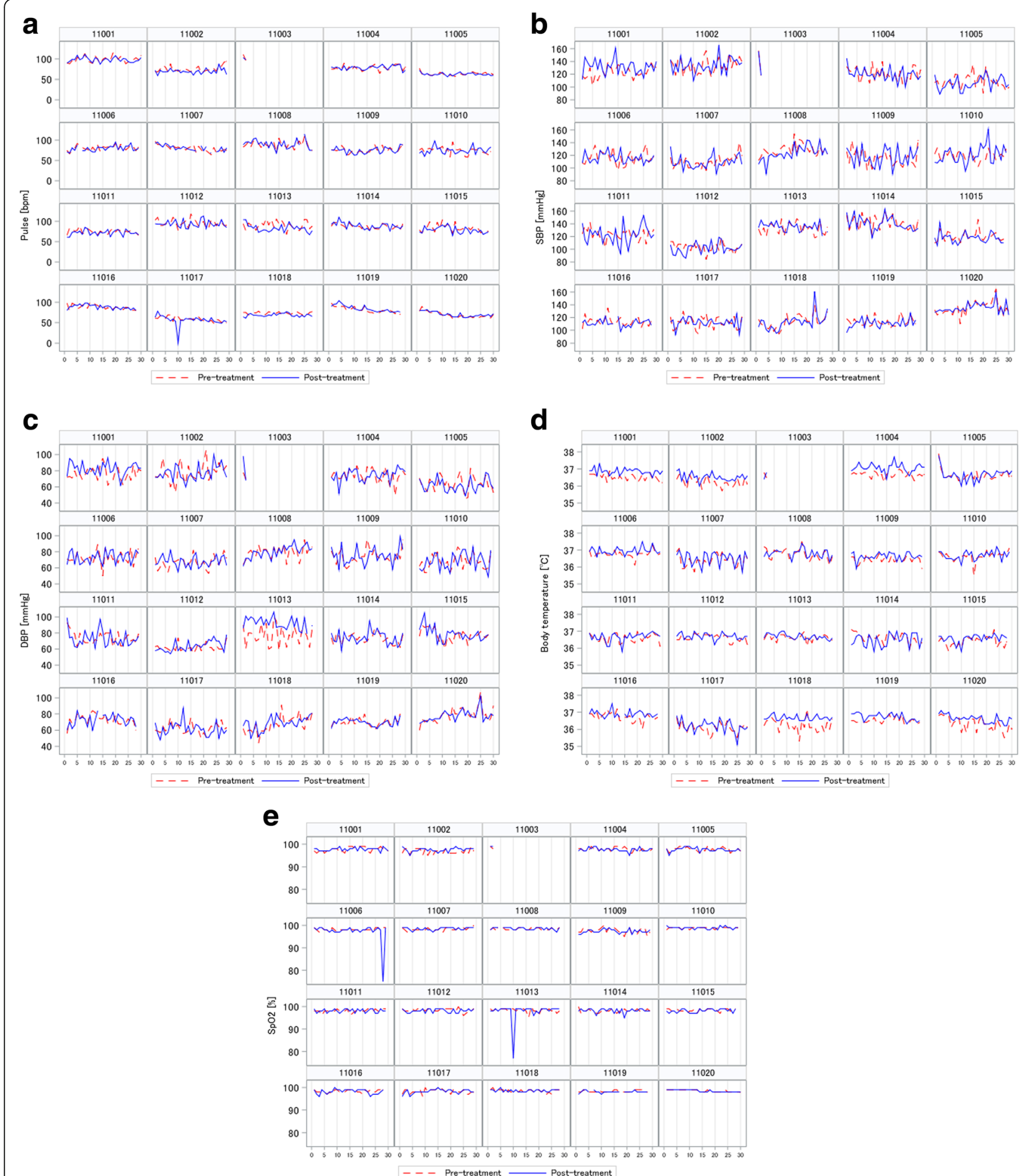

Fig. 1 Vital signs of patient cohort. The horizontal axis represents days. The dashed line shows the values measured before $\mathrm{CO}_{2}$ therapy, and the solid line shows the values measured after $\mathrm{CO}_{2}$ therapy. a Pulse, $\mathbf{b}$ systolic blood pressure, c diastolic blood pressure, $\mathbf{d}$ body temperature, and e $\mathrm{SpO}_{2}$ 
Table 2 Arterial gas analysis

\begin{tabular}{llllll}
\hline & Unit & Before the $\mathrm{CO}_{2}$ therapy & After the $\mathrm{CO}_{2}$ therapy & Difference between the means & 95\%Cl for the difference \\
\hline $\mathrm{BE}$ & $\mathrm{mmol} / \mathrm{L}$ & $-0.05(-1.60$ to 2.10$)$ & $0.18(-2.30$ to 2.50$)$ & $0.23(-1.90$ to 1.40$)$ & {$[-0.11$ to 0.57$]$} \\
$\mathrm{HCO}_{3^{-}}$ & $\mathrm{mmol} / \mathrm{L}$ & $24.18(22.90-26.50)$ & $24.53(22.20-27.40)$ & $0.35(-1.40$ to 1.50$)$ & {$[-0.02$ to 0.71$]$} \\
$\mathrm{O}_{2} \mathrm{SAT}$ & $\%$ & $97.50(96.10-99.90)$ & $97.37(92.40-100.00)$ & $-0.13(-4.00$ to 3.30$)$ & {$[-0.90$ to 0.64$]$} \\
$\mathrm{PaCO}_{2}$ & $\mathrm{mmHg}$ & $40.13(33.70-43.80)$ & $41.02(34.30-47.50)$ & $0.89(-6.00$ to 7.50$)$ & {$[-0.50$ to 2.28$]$} \\
$\mathrm{PaO}_{2}$ & $\mathrm{mmHg}$ & $93.54(76.80-132.00)$ & $99.14(76.40-167.00)$ & $5.60(-13.00$ to 86.90$)$ & {$[-5.36$ to 16.56$]$} \\
$\mathrm{pH}$ & $\mathrm{mU} / \mathrm{dL}$ & $7.40(7.36-7.45)$ & $7.39(7.35-7.44)$ & $-0.00(-0.06$ to 0.04$)$ & {$[-0.02$ to 0.01$]$} \\
Deoxy-Hb & $\%$ & $2.44(0.10-3.80)$ & $2.58(0.00-7.60)$ & $0.14(-3.20$ to 4.10$)$ & {$[-0.62$ to 0.90$]$} \\
Oxy- $\mathrm{Hb}$ & $\%$ & $95.21(92.60-97.10)$ & $95.24(92.20-97.60)$ & $0.04(-2.40$ to 3.20$)$ & {$[-0.61$ to 0.68$]$} \\
\hline
\end{tabular}

Values are expressed as mean (range). $n=19$

$\mathrm{BE}$ base excess, $\mathrm{HCO}_{3}$ - bicarbonate ion, $\mathrm{O}_{2} \mathrm{SAT}$ oxygen saturation, $\mathrm{PaCO}_{2}$ partial pressure of carbon dioxide in arterial blood, $\mathrm{PaO}$, partial pressure of oxygen in arterial blood, $\mathrm{pH}$ power of hydrogen, Deoxy-Hb deoxyhemoglobin, Oxy-Hb oxygenated hemoglobin, $95 \% \mathrm{Cl} 95 \% \mathrm{confidence}$ interval

observed due to application of the hydrogel to the skin. Moreover, there were no surgical site infections or clinical hypercapnia.

\section{Radiographic and clinical fracture union assessment} Radiographic fracture union was completed for all patients (Fig. 2). Clinical fracture union was also achieved for all patients.

\section{Measurement of blood flow in patients' limbs}

Figure 3 illustrates the blood flow over time for each patient on day 28 at the fracture level (Fig. 3a) and at a site $5 \mathrm{~cm}$ from the fracture level (Fig. 3b). The solid and dotted lines represent the values for the fractured and contra-lateral healthy limb, respectively. Blood flow at 20 min in the fractured limb was higher than that in the contra-lateral healthy limb in 16 of the 19 patients $(84.2 \%)$ at the fracture level and in all 19 patients (100\%) at the site $5 \mathrm{~cm}$ from the fracture level. No marked differences in the dynamic tendency of blood flow were observed between patients with femur and tibia fractures or between those with fresh fractures and nonunions.
Table 4 summarizes the endpoint and the ratio of blood flow in the patients' fractured limbs from pretreatment to post-treatment on days 1, 14, and 28 . Based on these data, it was evident that $\mathrm{CO}_{2}$ therapy promoted an increase in blood flow in the fractured limbs. The mean values increased in a timedependent manner for both fracture and adjacent sites, and the mean ratios showed an approximate 2fold increase on day 28. The small $p$-values in both the tables indicate an increase in blood flow attributable to $\mathrm{CO}_{2}$ therapy compared to pre-treatment measurements.

We then performed a sub-group analysis of enhanced blood flow by dividing patients into groups of $\leq 45$ ( $n=$ 9) and $>45(n=10)$ years of age, and the results are presented in Table 5 . We found a statistically significant difference on day 1 , measured at the fracture level ( $p=$ 0.030 ). The increase in blood flow was higher in the aged group. However, we did not find significant differences for the other conditions.

We also performed a sub-group analysis of enhanced blood flow by dividing patients based on treatment with

Table 3 Expired gas analysis data

\begin{tabular}{|c|c|c|c|c|c|}
\hline & Unit & Before $\mathrm{CO}_{2}$ therapy & During $\mathrm{CO}_{2}$ therapy & Difference between the means & $95 \% \mathrm{Cl}$ for the difference \\
\hline$\overline{\mathrm{ETCO}_{2}}$ & $\%$ & $4.78(4.16-5.59)$ & $4.76(4.28-5.51)$ & $-0.02(-0.34$ to 0.35$)$ & {$[-0.13$ to 0.09$]$} \\
\hline $\mathrm{ETO}_{2}$ & $\%$ & $16.05(4.57-17.43)$ & $16.08(14.08-17.09)$ & $0.03(-0.96$ to 0.95$)$ & {$[-0.21$ to 0.28$]$} \\
\hline R & N/A & $0.98(0.83-1.25)$ & $1.00(0.79-1.23)$ & $0.02(-0.06$ to 0.21$)$ & {$[-0.02$ to 0.06$]$} \\
\hline $\mathrm{VCO}_{2}$ & $\mathrm{~mL} / \mathrm{min}$ & $279.58(136.36-570.26)$ & $280.05(54.75-575.90)$ & 0.47 ( -116.0 to 93.08$)$ & [-22.66 to 23.61$]$ \\
\hline VE & $\mathrm{L} / \mathrm{min}$ & $9.48(5.99-15.30)$ & $9.47(2.20-15.20)$ & $-0.01(-4.54$ to 3.30$)$ & {$[-0.85$ to 0.82$]$} \\
\hline VENCO ${ }_{2}$ & N/A & $38.74(20.54-59.23)$ & $39.71(23.26-61.19)$ & $0.97(-7.48$ to 12.58$)$ & [-1.38 to 3.32$]$ \\
\hline $\mathrm{VE} / \mathrm{NO}_{2}$ & N/A & $36.82(20.39-49.54)$ & $38.20(26.04-49.56)$ & $1.39(-8.02$ to 12.88$)$ & [-1.51 to 4.29$]$ \\
\hline $\mathrm{VO}_{2}$ & $\mathrm{~mL} / \mathrm{min}$ & $274.04(63.67-499.26)$ & $272.64(53.00-518.14)$ & $-1.40(-105.4$ to 144.33$)$ & {$[-32.32$ to 29.52$]$} \\
\hline
\end{tabular}

Values are expressed as mean (range). $n=19$

$E T C \mathrm{O}_{2}$ end tidal carbon dioxide, $E T O_{2}$ end tidal oxygen, $R$ respiratory exchange ratio $\left(\mathrm{VCO}_{2} / \mathrm{VO}_{2}\right), V C \mathrm{~V}_{2}$ carbon dioxide output volume, $V E$ expiratory minute ventilation, $\mathrm{VO}_{2}$ oxygen uptake volume, $95 \% \mathrm{Cl} 95 \%$ confidence interval, $\mathrm{N} / \mathrm{A}$ not applicable 


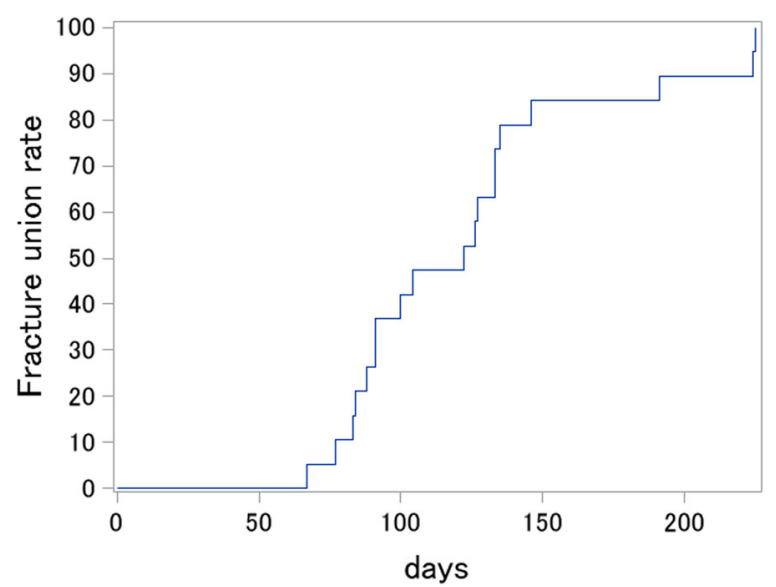

Fig. 2 Kaplan-Meier survival curve of fracture union. The horizontal axis represents the days from surgery to treat fracture/nonunion. The vertical axis represents the radiographic fracture union rate

intramedullary (IM) nailing $(n=9)$, plate $(n=9)$, and neither IM nailing nor plate $(n=1)$, and the results are presented in Table 6 . We found a statistically significant difference on day 14 , measured at the fracture level $(p=$ 0.040). The increase in blood flow was higher in the IM nailing group. However, we did not find significant differences for the other conditions.

Next, we performed a sub-group analysis of enhanced blood flow by dividing patients based on the initiation of weight bearing, specifically $\leq 5$ weeks $(n=7)$ and $>5$ weeks $(n=12)$ post-operation, and the results are presented in Table 7 . We found a statistically significant difference on day 28 , measured $5 \mathrm{~cm}$ from the fracture level $(p=0.047)$. The increase in blood flow was higher in the group with earlier initiation of weight bearing. However, we did not find significant differences for the other conditions.

We then performed a sub-group analysis of enhanced blood flow by dividing patients based on the affected bones, namely the femur $(n=8)$ and tibia $(n=11)$, and the results are presented in Table 8 . We found a statistically significant difference on day 14 , measured at the fracture level $(p=0.015)$. The increase in blood flow was higher in the femur group. However, we did not find significant differences for the other conditions.

Finally, we performed a sub-group analysis of enhanced blood flow by dividing patients into non-smoker $(n=5)$, current smoker $(n=12)$, and previous smoker $(n=2)$ groups, and the results are presented in Table 9. We found statistically significant differences on days 14 and 28 , measured at $5 \mathrm{~cm}$ from the fracture level $(p=$ 0.036 each). However, we did not find significant differences for the other conditions.
Blood flow data in the contra-lateral healthy leg were also analyzed. We found a statistically significant increase in blood flow in the contra-lateral healthy leg, and the results are presented in Table 10.

\section{Discussion}

Given that $\mathrm{CO}_{2}$ therapy introduces $\mathrm{CO}_{2}$ into the body, there have been concerns regarding the potential occurrence of hypercapnia. In this study, however, we demonstrated that the $\mathrm{CO}_{2}$ therapy that we used causes no adverse events including hypercapnia in patients. The successful verification of the safety of $\mathrm{CO}_{2}$ therapy was the main outcome of the current clinical trial. This favorable outcome supports the validity of continuing assessments of this $\mathrm{CO}_{2}$ therapy in further clinical trials with patients.

In addition to the effect of accelerating fracture healing, various positive effects of $\mathrm{CO}_{2}$ therapy have been reported in pre-clinical studies. One example is the effects of $\mathrm{CO}_{2}$ therapy on muscles, which include muscle fiber switching in skeletal muscle [27], acceleration of muscle injury repair [28], and acceleration of the performance of endurance exercise [29]. Another example relates to the effects of this therapy on tumors. $\mathrm{CO}_{2}$ therapy has been demonstrated to have inherent antitumor effects [30-33] by suppressing metastasis [33, 34], enhancing the antitumor effect of radiation therapy [35, 36], and suppressing bone destruction caused by bone metastasis [37]. All of these are targets that warrant further examination in clinical trials. The clinical trial reported herein is the first such trial involving human patients, and therefore, the information we provide regarding the proven safety of $\mathrm{CO}_{2}$ therapy will be valuable to other investigators conducting future clinical trials for various diseases.

We focused on blood flow in this study because it is one of the most critical factors associated with fracture repair. Poor vascularity adversely affects fracture repair [38-40] and is a risk factor for nonunion [41]; it has also been reported as a target for treatment to improve nonunion [42]. Angiogenesis is a key component of bone repair [43, 44] and modern fracture fixation techniques such as biological osteosynthesis and minimally invasive plate osteosynthesis, which are aimed at preserving vascularity around the fracture site to enhance fracture healing [45-49]. Therefore, we adopted blood flow in the fractured limb as a surrogate endpoint signifying a positive effect on fracture repair.

Based on the measurements obtained in the present study, it is evident that $\mathrm{CO}_{2}$ therapy can effectively increase blood flow in the fractured limbs. Additionally, in the majority of patients, we recorded higher blood flow in the fractured limb than in the contra- 
a Fracture level

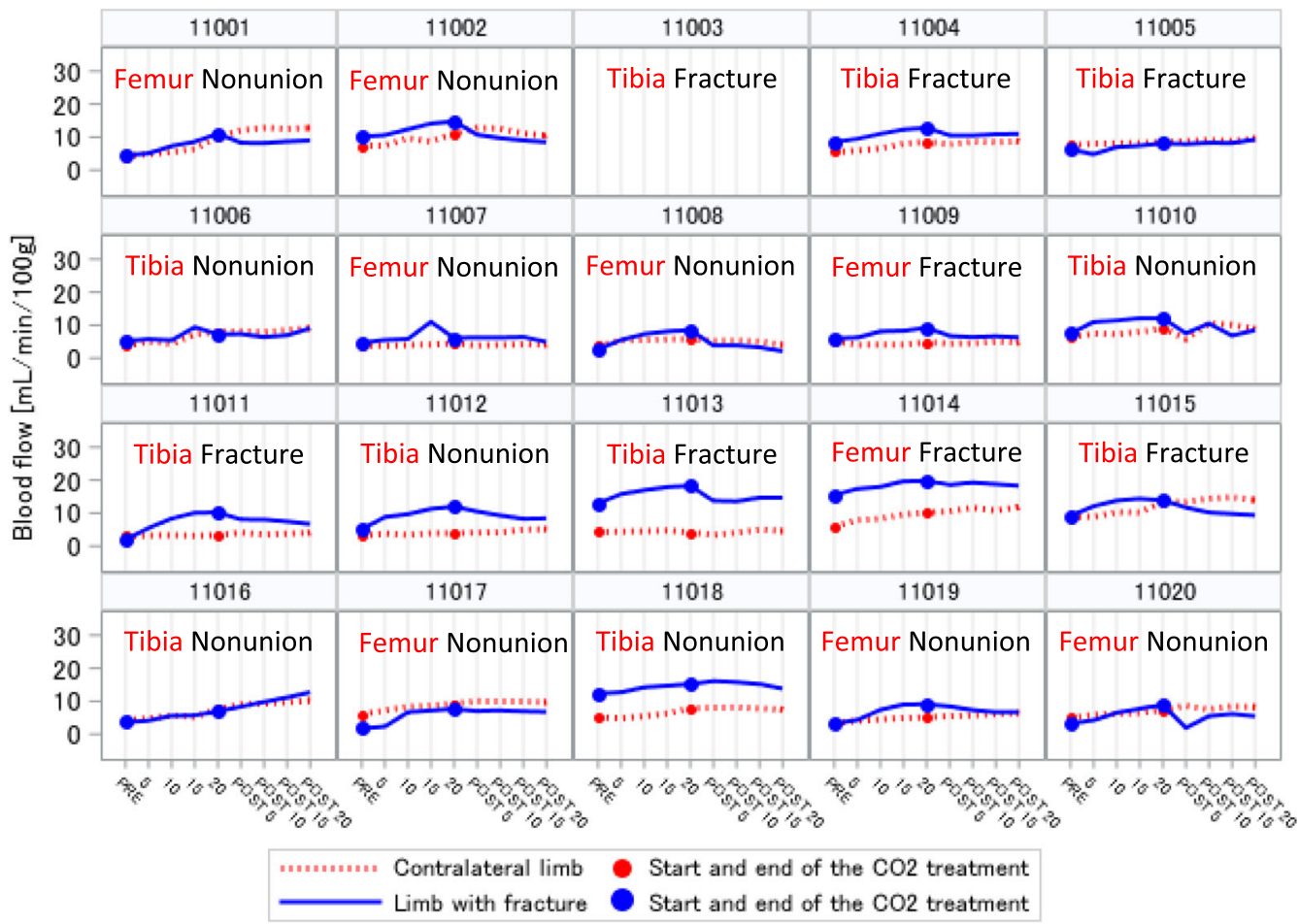

b

$5 \mathrm{~cm}$ from the fracture level

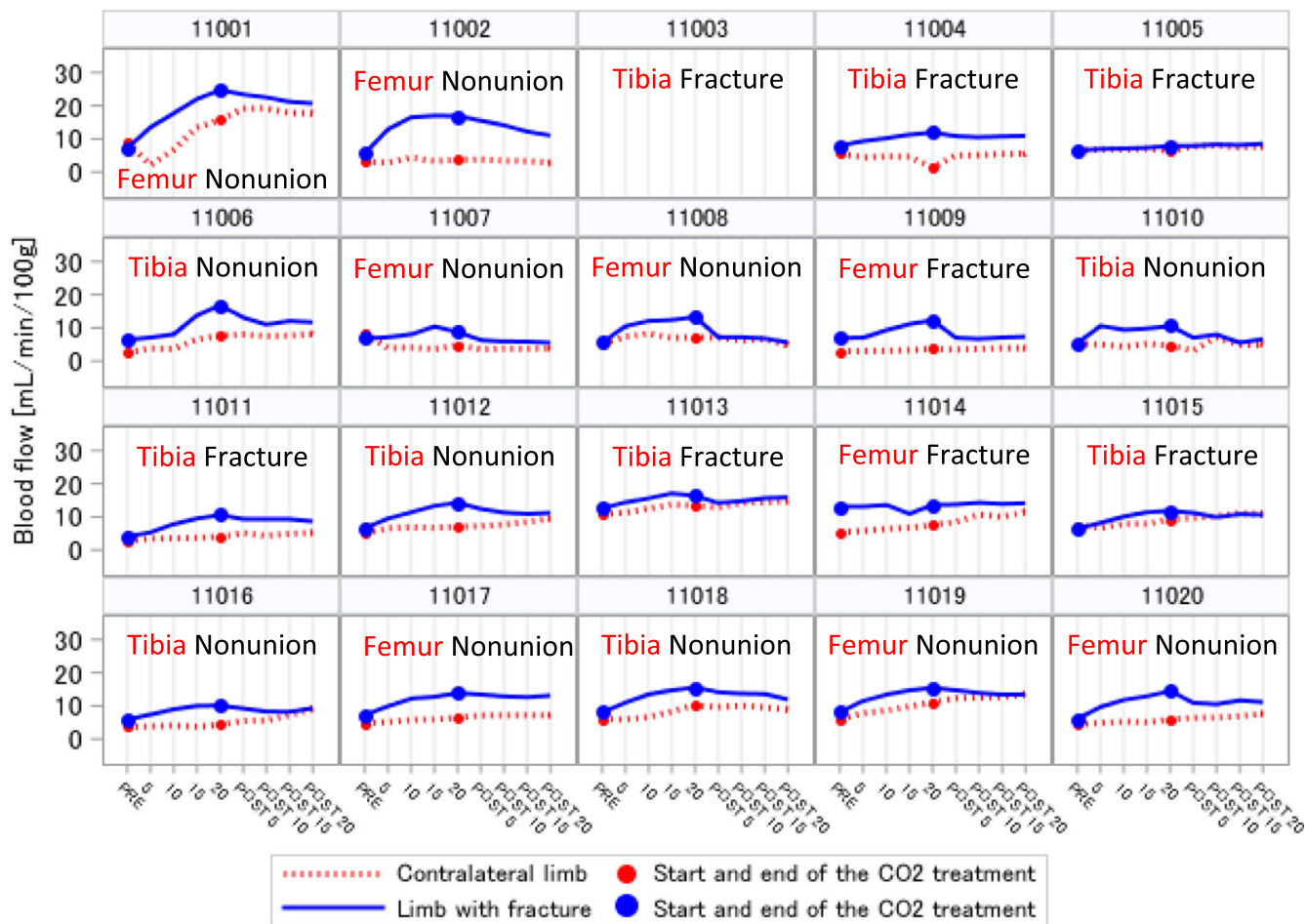

Fig. 3 (See legend on next page.) 
(See figure on previous page.)

Fig. 3 Blood flow in patient limbs on day 28 after the initiation of $\mathrm{CO}_{2}$ therapy. The horizontal axis indicates the time course. Blood flow was measured continuously from prior to the commencement of the $\mathrm{CO}_{2}$ therapy (PRE) to 20 min after (POST) a 20-min session of the $\mathrm{CO}_{2}$ therapy. The vertical axis shows the blood flow. The affected bone (femur or tibia) and whether the fracture is a fresh fracture or a fracture with nonunion are indicated. The solid line shows the blood flow in the fractured limb and the dotted line shows the blood flow in the contra-lateral healthy limb. Filled circles on the lines indicate the time point of the start and end of the $\mathrm{CO}_{2}$ therapy. a Blood follow measured at the fracture level. $\mathbf{b}$ Blood follow measured at a point $5 \mathrm{~cm}$ from the fracture level

lateral healthy limb (Fig. 3). As indicated in Table 4, blood flow showed a time-dependent increase throughout treatment. This phenomenon can be attributed to one or both of the following processes. First, the effect of increased blood flow promoted by $\mathrm{CO}_{2}$ therapy is reinforced by the continuation of daily $\mathrm{CO}_{2}$ therapy. Second, the vascularity of the fractured limb itself increases with time after surgery, which reflects the course of the healing process. It is possible that new blood vessel formation occurs with time after surgery. Moreover, there is an increase in the number of blood vessels that can respond to the effect of increased blood flow promoted by $\mathrm{CO}_{2}$ therapy. We additionally analyzed the data of blood flow in the contra-lateral healthy leg as shown in Table 10. We also found a statistically significant increase in blood flow in the contra-lateral healthy leg. This could be because the $\mathrm{CO}_{2}$ therapy induced some systemic effects to increase blood flow, and the increased blood flow observed in the fractured limbs was not induced only by the fracture healing process.

In the present study, we measured blood flow at two different points in the fractured limb, specifically at the fracture level and at a site $5 \mathrm{~cm}$ from the fracture level. In some cases, during surgery, the skin at the fracture site is incised, and this raises concerns because surgical incision might disrupt the vascularity of soft tissue at the fracture level. Therefore, in the present study, we decided to additionally measure blood flow at a point in the ipsilateral limb slightly removed from the fracture level. Consequently, it was evident that an increase in blood flow was promoted at both the fracture level and its surroundings. The increase in blood flow in the fractured limb was accordingly deemed to contribute to fracture repair. A similar tendency of increased blood flow was observed for cases of femur and tibia fractures, and in both fresh fractures and fractures with nonunion. However, further in-depth analysis is needed to determine the possible differences between femur and tibia fractures and fresh fractures and those with nonunion.

Despite the small number of patients, owing to the nature of this small-sized, early phase clinical trial, we performed sub-group analyses. We found some statistically significant differences; however, we cannot definitely conclude that the factors analyzed affect the blood flow-enhancing effects of the $\mathrm{CO}_{2}$ therapy. It is still unclear whether age, type of osteosynthesis, time of initiation of weight bearing, affected bone (femur or tibia), and smoking status affect $\mathrm{CO}_{2}$ therapy outcomes to enhance blood flow in the present smallsized clinical trial. Although it cannot be neglected that the number of patients was small in the present study, we found some significant findings. It seems that age does not significantly contribute to the effect of $\mathrm{CO}_{2}$ therapy on enhance blood flow. It is possible that IM nailing affects the bone circulation by damaging the endosteal blood supply; in contrast, IM nailing can preserve the periosteal blood supply. Therefore, it is possible that $\mathrm{CO}_{2}$ therapy is more effective in enhancing blood flow around the bone in the fractured limb treated by IM nailing. It is possible that an earlier weight bearing reinforces the effect of the $\mathrm{CO}_{2}$ therapy to enhance blood flow. Further, the

Table 4 Increase in blood flow promoted by the $\mathrm{CO}_{2}$ therapy in the fractured limb of patients

\begin{tabular}{llll}
\hline Measuring site & Treatment day & Mean (range) [95\%Cl] & $p$-value \\
\hline Fracture level & 1 & $1.414(0.970-2.846)[1.218-1.611]$ & $p<0.00001$ \\
& 14 & $1.764(1.156-3.152)[1.491-2.036]$ & $p<0.00001$ \\
$5 \mathrm{~cm}$ from the fracture level & 28 & $2.137(1.236-5.100)[1.602-2.673]$ & $p<0.00001$ \\
& 1 & $1.478(1.010-2.000)[1.344-1.612]$ & $p<0.00001$ \\
& 14 & $1.855(1.168-2.660)[1.623-2.087]$ & $p<0.00001$ \\
& 28 & $1.997(1.038-3.431)[1.694-2.300]$ & $p<0.00001$ \\
\hline
\end{tabular}

Blood flow increase is demonstrated by the ratio of blood flow measured after $20 \mathrm{~min}$ of $\mathrm{CO}_{2}$ therapy to that at pre-treatment. Number of patients $=19 . p$-value: calculated using Wilcoxon signed rank test with a null hypothesis that the population mean of the blood flow ratio is 1 
Table 5 Sub-group analysis regarding the influence of age on the increase in blood flow by the $\mathrm{CO}_{2}$ therapy in the fractured limb of patients

\begin{tabular}{|c|c|c|c|c|c|c|}
\hline Measuring site & Treatment day & Age & $n$ & Mean (range) $[95 \% \mathrm{Cl}]$ & $p$-value (1) & $p$-value (2) \\
\hline \multirow[t]{6}{*}{ Fracture level } & \multirow[t]{2}{*}{1} & $\leq 45$ & 9 & $1.221(0.970-1.473)[1.106-1.336]$ & 0.008 & \multirow[t]{2}{*}{0.030} \\
\hline & & $>45$ & 10 & $1.589(1.146-2.846)$ [1.238-1.940] & 0.002 & \\
\hline & \multirow[t]{2}{*}{14} & $\leq 45$ & 9 & $1.750(1.184-3.152)$ [1.289-2.211] & 0.004 & \multirow[t]{2}{*}{0.97} \\
\hline & & $>45$ & 10 & $1.777(1.156-2.829)$ [1.372-2.181] & 0.002 & \\
\hline & \multirow[t]{2}{*}{28} & $\leq 45$ & 9 & $2.101(1.326-5.100)$ [1.135-3.068] & 0.004 & \multirow[t]{2}{*}{0.97} \\
\hline & & $>45$ & 10 & $2.170(1.236-4.471)$ [1.432-2.907] & 0.002 & \\
\hline \multirow[t]{6}{*}{$5 \mathrm{~cm}$ from the fracture level } & \multirow[t]{2}{*}{1} & $\leq 45$ & 9 & $1.453(1.010-1.705)$ [1.290-1.615] & 0.004 & \multirow[t]{2}{*}{0.77} \\
\hline & & $>45$ & 10 & $1.501(1.060-2.000)$ [1.260-1.742] & 0.002 & \\
\hline & \multirow[t]{2}{*}{14} & $\leq 45$ & 9 & $1.811(1.314-2.440)$ [1.506-2.116] & 0.004 & \multirow[t]{2}{*}{0.78} \\
\hline & & $>45$ & 10 & 1.895 (1.168-2.660) [1.490-2.300] & 0.002 & \\
\hline & \multirow[t]{2}{*}{28} & $\leq 45$ & 9 & 1.908 (1.279-2.625) [1.507-2.309] & 0.004 & \multirow[t]{2}{*}{0.71} \\
\hline & & $>45$ & 10 & $2.077(1.038-3.431)$ [1.555-2.600] & 0.002 & \\
\hline
\end{tabular}

Blood flow increase is demonstrated by the ratio of blood flow measured after 20 min of $\mathrm{CO}_{2}$ therapy to that at pre-treatment. $\mathrm{n}$ : number of patients. $p$-value (1): calculated using Wilcoxon signed rank test with a null hypothesis that the population mean of the blood flow ratio is 1. $p$-value (2): calculated using MannWhitney $\mathrm{U}$ test to compare the two groups (Age $\leq 45$ versus $>45$ )

effect of the $\mathrm{CO}_{2}$ therapy to enhance blood flow might be higher for patients with femur fracture than for those with tibia fracture because the femur has more abundant adjacent soft tissues and inherent vascularity supplied from the surroundings compared to those of the tibia. Our data indicate that the effect of
$\mathrm{CO}_{2}$ therapy in enhancing blood flow is evident even in smokers. We consider that the blood flow in smokers who tend to have less vascularity than nonsmokers can also be increased by the $\mathrm{CO}_{2}$ therapy. However, the small number of patients in the present study should be considered while interpreting the

Table 6 Sub-group analysis regarding the influence of the type of osteosynthesis on the increase in blood flow by the $\mathrm{CO}_{2}$ therapy in the fractured limb of patients

\begin{tabular}{|c|c|c|c|c|c|c|}
\hline Measuring site & Treatment day & Type of osteosynthesis & $n$ & Mean (range) $[95 \% \mathrm{Cl}]$ & $p$-value (1) & $p$-value (2) \\
\hline \multirow[t]{9}{*}{ Fracture level } & \multirow[t]{3}{*}{1} & IMN & 9 & $1.523(0.970-2.846)[1.096-1.950]$ & 0.008 & \multirow[t]{3}{*}{0.41} \\
\hline & & Plate & 9 & $1.336(1.080-1.618)$ [1.192-1.480] & 0.004 & \\
\hline & & Other & 1 & 1.146 & & \\
\hline & \multirow[t]{3}{*}{14} & $\mathrm{IMN}$ & 9 & $2.124(1.158-3.152)$ [1.642-2.606] & 0.004 & \multirow[t]{3}{*}{0.040} \\
\hline & & Plate & 9 & $1.448(1.156-1.720)$ [1.278-1.618] & 0.002 & \\
\hline & & Other & 1 & 1.362 & & \\
\hline & \multirow[t]{3}{*}{28} & IMN & 9 & $2.363(1.236-4.471)$ [1.533-3.192] & 0.004 & \multirow[t]{3}{*}{0.50} \\
\hline & & Plate & 9 & $1.888(1.306-5.100)$ [0.952-2.824] & 0.004 & \\
\hline & & Other & 1 & 2.353 & & \\
\hline \multirow[t]{9}{*}{$5 \mathrm{~cm}$ from the fracture level } & \multirow[t]{3}{*}{1} & IMN & 9 & $1.451(1.010-2.000)$ [1.175-1.726] & 0.004 & \multirow[t]{3}{*}{0.36} \\
\hline & & Plate & 9 & $1.468(1.164-1.705)$ [1.334-1.602] & 0.004 & \\
\hline & & Other & 1 & 1.816 & & \\
\hline & \multirow[t]{3}{*}{14} & IMN & 9 & $2.119(1.168-2.660)$ [1.701-2.538] & 0.004 & \multirow[t]{3}{*}{0.09} \\
\hline & & Plate & 9 & $1.592(1.206-2.091)$ [1.390-1.793] & 0.004 & \\
\hline & & Other & 1 & 1.851 & & \\
\hline & \multirow[t]{3}{*}{28} & IMN & 9 & $2.216(1.038-3.431)[1.680-2.752]$ & 0.004 & \multirow[t]{3}{*}{0.20} \\
\hline & & Plate & 9 & $1.759(1.215-2.625)$ [1.351-2.167] & 0.004 & \\
\hline & & Other & 1 & 2.167 & & \\
\hline
\end{tabular}

Blood flow increase is demonstrated by the ratio of blood flow measured after 20 min of $\mathrm{CO}_{2}$ therapy to that at pre-treatment. $\mathrm{n}$ : number of patients. $p$-value (1): calculated using Wilcoxon signed rank test with a null hypothesis that the population mean of the blood flow ratio is 1. $p$-value (2): calculated using KruskalWallis test to compare the three groups (IMN versus plate versus other). IMN: intramedullary nailing 
Table 7 Sub-group analysis regarding the influence of weight bearing on the increase in blood flow by the $\mathrm{CO}_{2}$ therapy in the fractured limb of patients

\begin{tabular}{|c|c|c|c|c|c|c|}
\hline Measuring site & Treatment day & Weight bearing (weeks) & $n$ & Mean (range) $[95 \% \mathrm{Cl}]$ & $p$-value (1) & $p$-value (2) \\
\hline \multirow[t]{6}{*}{ Fracture level } & \multirow[t]{2}{*}{1} & $\leq 5$ & 7 & $1.490(1.080-2.846)$ [0.922-2.057] & 0.016 & \multirow[t]{2}{*}{0.77} \\
\hline & & $>5$ & 12 & $1.371(0.970-1.825)$ [1.215-1.526] & $<0.001$ & \\
\hline & \multirow[t]{2}{*}{14} & $\leq 5$ & 7 & $2.119(1.158-3.152)$ [1.439-2.800] & 0.016 & \multirow[t]{2}{*}{0.14} \\
\hline & & $>5$ & 12 & $1.556(1.156-2.145)$ [1.355-1.758] & $<0.001$ & \\
\hline & \multirow[t]{2}{*}{28} & $\leq 5$ & 7 & $2.190(1.277-3.148)$ [1.455-2.925] & 0.016 & \multirow[t]{2}{*}{0.64} \\
\hline & & $>5$ & 12 & $2.107(1.236-5.100)$ [1.284-2.929] & $<0.001$ & \\
\hline \multirow[t]{6}{*}{$5 \mathrm{~cm}$ from the fracture level } & \multirow[t]{2}{*}{1} & $\leq 5$ & 7 & $1.449(1.060-2.000)$ [1.177-1.721] & 0.016 & \multirow[t]{2}{*}{0.74} \\
\hline & & $>5$ & 12 & $1.495(1.010-2.000)$ [1.317-1.673] & $<0.001$ & \\
\hline & \multirow[t]{2}{*}{14} & $\leq 5$ & 7 & $2.116(1.168-2.660)$ [1.544-2.688] & 0.016 & \multirow[t]{2}{*}{0.19} \\
\hline & & $>5$ & 12 & $1.703(1.206-2.346)$ [1.500-1.906] & $<0.001$ & \\
\hline & \multirow[t]{2}{*}{28} & $\leq 5$ & 7 & $2.397(1.038-3.431)$ [1.682-3.112] & 0.016 & \multirow[t]{2}{*}{0.047} \\
\hline & & $>5$ & 12 & $1.764(1.215-2.585)$ [1.510-2.018] & $<0.001$ & \\
\hline
\end{tabular}

Blood flow increase is demonstrated by the ratio of blood flow measured after 20 min of $\mathrm{CO}_{2}$ therapy to that at pre-treatment. $\mathrm{n}$ : number of patients. $p$-value (1): calculated using Wilcoxon signed rank test with a null hypothesis that the population mean of the blood flow ratio is 1 . $p$-value (2): calculated using MannWhitney $\mathrm{U}$ test to compare the two groups (weight bearing initiated $\leq 5$ weeks versus $>5$ weeks)

results. These issues will be the target of future large-sized clinical trials with more homogeneous populations.

This study has some limitations. The sample size was small and included a heterogeneous population of patients. We included patients with femur and tibia fractures and those with fresh fractures and nonunions in accordance with the nature of this study (an early-phase clinical trial). It was evident that $\mathrm{CO}_{2}$ therapy promoted an increase in blood flow in the fractured limbs of patients; however, it remains to be determined whether this increase has a direct positive effect on fracture repair. Currently, we do not possess radiological data to confirm the acceleration of fracture repair because this clinical trial was designed mainly to assess the safety. The true endpoint of studies investigating fracture repair is the acceleration of bony union, and accordingly, this would be a target for further studies. Moreover, the measurement of blood flow using a laser Doppler blood flow meter reflects superficial micro-circulation; however, in our previous study on healthy volunteers using phosphorus-31 magnetic resonance spectroscopy, we found that $\mathrm{CO}_{2}$ therapy affected the deep tissue, triceps surae muscle, via changes in intramuscular $\mathrm{pH}[26]$.

Table 8 Sub-group analysis regarding the influence of affected bone on the increase in blood flow by the $\mathrm{CO}_{2}$ therapy in the fractured limb of patients

\begin{tabular}{|c|c|c|c|c|c|c|}
\hline Measuring site & Treatment day & Affected bone & $n$ & Mean (range) $[95 \% \mathrm{Cl}]$ & $p$-value (1) & $p$-value (2) \\
\hline \multirow[t]{6}{*}{ Fracture level } & \multirow[t]{2}{*}{1} & Femur & 8 & $1.518(1.153-2.846)$ [1.054-1.982] & 0.008 & \multirow[t]{2}{*}{0.59} \\
\hline & & Tibia & 11 & $1.339(0.970-1.825)$ [1.164-1.514] & 0.002 & \\
\hline & \multirow[t]{2}{*}{14} & Femur & 8 & $2.162(1.158-3.152)$ [1.637-2.687] & 0.008 & \multirow[t]{2}{*}{0.015} \\
\hline & & Tibia & 11 & $1.474(1.156-2.145)$ [1.283-1.665] & $<0.001$ & \\
\hline & \multirow[t]{2}{*}{28} & Femur & 8 & $2.468(1.277-4.471)$ [1.548-3.387] & 0.008 & \multirow[t]{2}{*}{0.30} \\
\hline & & Tibia & 11 & $1.897(1.236-5.100)$ [1.153-2.641] & $<0.001$ & \\
\hline \multirow[t]{6}{*}{$5 \mathrm{~cm}$ from the fracture level } & \multirow[t]{2}{*}{1} & Femur & 8 & $1.428(1.060-2.000)$ [1.198-1.659] & 0.008 & \multirow[t]{2}{*}{0.28} \\
\hline & & Tibia & 11 & $1.514(1.010-2.000)$ [1.321-1.707] & $<0.001$ & \\
\hline & \multirow[t]{2}{*}{14} & Femur & 8 & $2.073(1.168-2.660)$ [1.578-2.567] & 0.008 & \multirow[t]{2}{*}{0.20} \\
\hline & & Tibia & 11 & $1.697(1.206-2.346)$ [1.478-1.917] & $<0.001$ & \\
\hline & \multirow[t]{2}{*}{28} & Femur & 8 & $2.167(1.038-3.431)$ [1.489-2.845] & 0.008 & \multirow[t]{2}{*}{0.48} \\
\hline & & Tibia & 11 & $1.874(1.215-2.625)$ [1.565-2.182] & $<0.001$ & \\
\hline
\end{tabular}

Blood flow increase is demonstrated by the ratio of blood flow measured after 20 min of $\mathrm{CO}_{2}$ therapy to that at pre-treatment. n: number of patients. $p$-value (1): calculated using Wilcoxon signed rank test with a null hypothesis that the population mean of the blood flow ratio is 1 . $p$-value (2): calculated using MannWhitney $\mathrm{U}$ test to compare the two groups (femur versus tibia) 
Table 9 Sub-group analysis regarding the influence of smoking on the increase in blood flow by the $\mathrm{CO}_{2}$ therapy in the fractured limb of patients

\begin{tabular}{|c|c|c|c|c|c|c|}
\hline Measuring site & Treatment day & Smoking status & $\mathrm{n}$ & Mean (range) $[95 \% \mathrm{Cl}]$ & $p$-value (1) & $p$-value (2) \\
\hline \multirow[t]{9}{*}{ Fracture level } & \multirow[t]{3}{*}{1} & Non-smoker & 5 & $1.377(1.153-1.618)$ [1.117-1.637] & 0.063 & \multirow[t]{3}{*}{0.65} \\
\hline & & Current smoker & 12 & $1.429(0.970-2.846)$ [1.109-1.749] & $<0.001$ & \\
\hline & & Previous smoker & 2 & $1.420(1.366-1.473)[0.739-2.100]$ & 0.50 & \\
\hline & \multirow[t]{3}{*}{14} & Non-smoker & 5 & $1.656(1.156-2.057)$ [1.202-2.110] & 0.063 & \multirow[t]{3}{*}{0.055} \\
\hline & & Current smoker & 12 & 1.899 (1.184-3.152) [1.500-2.299] & $<0.001$ & \\
\hline & & Previous smoker & 2 & $1.220(1.158-1.281)[0.436-2.003]$ & 0.50 & \\
\hline & \multirow[t]{3}{*}{28} & Non-smoker & 5 & $1.692(1.306-2.844)[0.884-2.500]$ & 0.063 & \multirow[t]{3}{*}{0.12} \\
\hline & & Current smoker & 12 & $2.455(1.236-5.100)$ [1.664-3.247] & $<0.001$ & \\
\hline & & Previous smoker & 2 & $1.343(1.277-1.408)$ [0.515-2.170] & 0.50 & \\
\hline \multirow[t]{9}{*}{$5 \mathrm{~cm}$ from the fracture level } & \multirow[t]{3}{*}{1} & Non-smoker & 5 & $1.457(1.164-2.000)$ [1.062-1.852] & 0.063 & \multirow[t]{3}{*}{0.93} \\
\hline & & Current smoker & 12 & $1.503(1.010-2.000)$ [1.337-1.669] & $<0.001$ & \\
\hline & & Previous smoker & 2 & $1.382(1.060-1.705)[-2.71-5.478]$ & 0.50 & \\
\hline & \multirow[t]{3}{*}{14} & Non-smoker & 5 & $1.719(1.206-2.611)$ [1.064-2.374] & 0.063 & \multirow[t]{3}{*}{0.036} \\
\hline & & Current smoker & 12 & 2.015 (1.453-2.660) [1.751-2.278] & $<0.001$ & \\
\hline & & Previous smoker & 2 & $1.241(1.168-1.314)[0.313-2.168]$ & 0.50 & \\
\hline & \multirow[t]{3}{*}{28} & Non-smoker & 5 & $1.842(1.215-3.018)$ [0.942-2.742] & 0.063 & \multirow[t]{3}{*}{0.036} \\
\hline & & Current smoker & 12 & $2.200(1.488-3.431)[1.868-2.531]$ & $<0.001$ & \\
\hline & & Previous smoker & 2 & $1.170(1.038-1.302)[-.504-2.843]$ & 0.50 & \\
\hline
\end{tabular}

Blood flow increase is demonstrated by the ratio of blood flow measured after 20 min of $\mathrm{CO}_{2}$ therapy to that at pre-treatment. $\mathrm{n}$ : number of patients. $p$-value (1): calculated using Wilcoxon signed rank test with a null hypothesis that the population mean of the blood flow ratio is 1 . $p$-value (2): calculated using KruskalWallis test to compare the three groups (Non-smoker versus current smoker versus previous smoker)

Nevertheless, we believe that the questions we sought to answer in this study, namely, whether $\mathrm{CO}_{2}$ therapy is safe and effective to increase blood flow in the fractured limbs of patients, have been satisfactorily addressed. Given that $\mathrm{CO}_{2}$ therapy increases blood flow, this type of therapy is expected to be beneficial for the treatment of open fractures, fractures in patients with ischemic disease or diabetes mellitus, fractures in smokers, and avascular nonunions. In addition to an increase in blood flow, local oxygenation via the Bohr effect [26] is also expected to contribute to tissue healing. Moreover, positive effects related not only to the healing of bone but also to that of soft tissue can be expected. Whether $\mathrm{CO}_{2}$ therapy accelerates fracture repair, improves union rate, and shortens the time to union are still unclear, which necessitates further study; however, we believe that $\mathrm{CO}_{2}$ therapy is a promising new clinically applicable tool that can be used to assist fracture repair.

\section{Conclusions}

The topical cutaneous application of carbon dioxide via hydrogel has been shown to be clinically safe and to promote blood flow in fractured limbs in a small sample of patients.

Table 10 Increase in blood flow promoted by the $\mathrm{CO}_{2}$ therapy in the contra-lateral non-fractured limb of patients

\begin{tabular}{lllll}
\hline Measuring site & Treatment day & Mean (range) [95\%Cl] & $p$-value \\
\hline Fracture level & 1 & $1.220(0.875-1.533)[1.140-1.300]$ & $<0.0001$ \\
& 14 & $1.431(0.831-2.139)[1.262-1.600]$ & $<0.0001$ \\
$5 \mathrm{~cm}$ from the fracture level & 28 & $1.493(0.941-2.429)[1.311-1.675]$ & $<0.0001$ \\
& 1 & $1.204(0.438-1.611)[1.068-1.339]$ & 0.009 & $<0.001$ \\
& 14 & $1.396(0.669-2.079)[1.228-1.564]$ & 0.011 \\
\hline
\end{tabular}

Blood flow increase is demonstrated by the ratio of blood flow measured after 20 min of $\mathrm{CO}_{2}$ therapy to that at pre-treatment. Number of patients $=19 . p$-value: calculated using Wilcoxon signed rank test with a null hypothesis that the population mean of the blood flow ratio is 1 


\section{Abbreviations}

$\mathrm{CO}_{2}$ : carbon dioxide; IM: intramedullary

\section{Acknowledgments}

We thank Dr. Yasuaki Ohnishi, Dr. Kenichi Sawauchi, Dr. Kazumichi Kitayama, Dr. Kiminari Kataoka, Dr. Kenji Kudo, Dr. Kohei Kamada, Dr. Takeo Tokura, Dr. Naotoshi Kumagai, Dr. Kyohei Takase, Dr. Tomohiro Miyamoto, Dr. Yu Sasaki, and Dr. Tomoya Matsuo for administering the daily $\mathrm{CO}_{2}$ therapy. We would also like to thank Dr. Seimi Satomi-Kobayashi for her contribution in interpreting the data of arterial and expired gas analyses, Dr. Yasunori Tsuboi for his contribution to expired gas analysis, and Ms. Hiromi Nagano for data management. We would like to thank Editage (www.editage.jp) for English language editing.

\section{Authors' contributions}

TN analyzed and interpreted the data and wrote the manuscript. TI managed the proper collection of all data. TO performed statistical analyses and contributed to writing the manuscript. SL and YS analyzed the arterial gas analysis data. TA and $\mathrm{KO}$ analyzed the expired gas analysis data. TF analyzed the data of vital signs. TM1 analyzed the blood flow data. TM2 analyzed radiographic assessment data. RK contributed to writing the manuscript. All authors have read and approved the final manuscript.

\section{Funding}

This study was supported by a grant from ZENKYOREN (National Mutual Insurance Federation of Agricultural Cooperatives, Japan), URL: http://social. ja-kyosai.or.jp/contribution/traffic06.html. The funding source had no role in the study design, data collection and analysis, decision to publish, or preparation of the manuscript.

\section{Availability of data and materials}

The datasets used and/or analyzed during the current study are available from the corresponding author upon reasonable request.

\section{Ethics approval and consent to participate}

The study protocol was approved by the Institutional Review Board of the Kobe University Hospital (Approved number: 260008). Prior to conducting the study, we obtained written informed consent from patients who were eligible.

\section{Consent for publication}

Written informed consent for the publication of personal or clinical data with protection of privacy was obtained from patients who were eligible.

\section{Competing interests}

The authors declare that they have no competing interests.

\section{Author details}

${ }^{1}$ Department of Orthopaedic Surgery, Kobe University Graduate School of Medicine, 7-5-1 Kusunoki-cho, Chuo-ku, Kobe 650-0017, Japan. ²Department of Orthopaedic Surgery, Hyogo Prefectural Awaji Medical Center, Sumoto, Japan. ${ }^{3}$ Division of Biostatistics, Department of Social/Community Medicine and Health Science, Kobe University School of Medicine, Kobe, Japan. ${ }^{4}$ Department of Orthopaedic Surgery, Showa University School of Medicine, Tokyo, Japan. ${ }^{5}$ Division of Rehabilitation Medicine, Kobe University Graduate School of Medicine, Kobe, Japan. 'Department of Rehabilitation Science, Kobe University Graduate School of Health Sciences, Kobe, Japan.

Received: 24 February 2019 Accepted: 23 October 2019

Published online: 25 November 2019

\section{References}

1. Morison Z, Vicente M, Schemitsch EH, McKee MD. The treatment of atrophic, recalcitrant long-bone nonunion in the upper extremity with human recombinant bone morphogenetic protein-7 (rhBMP-7) and plate fixation: a retrospective review. Injury. 2016;47:356-63.

2. Dai J, Li L, Jiang C, Wang C, Chen H, Chai Y. Bone morphogenetic protein for the healing of tibial fracture: a meta-analysis of randomized controlled trials. PLoS One. 2015;10:e0141670.
3. Papanagiotou M, Dailiana ZH, Karachalios T, Varitimidis S, Vlychou M, Hantes $\mathrm{M}$, et al. RhBMP-7 for the treatment of nonunion of fractures of long bones. Bone Joint J. 2015;97:997-1003.

4. Moghaddam A, Elleser C, Biglari B, Wentzensen A, Zimmermann G. Clinical application of BMP 7 in long bone non-unions. Arch Orthop Trauma Surg. 2010;130:71-6.

5. Govender S, Csimma C, Genant HK, Valentin-Opran A. BMP-2 Evaluation in Surgery for Tibial Trauma (BESTT) Study Group. Recombinant human bone morphogenetic protein-2 for treatment of open tibial fractures: a prospective, controlled, randomized study of four hundred and fifty patients. J Bone Joint Surg Am. 2002;84:2123-34.

6. Friedlaender GE, Perry CR, Cole JD, Cook SD, Cierny G, Muschler GF, et al. Osteogenic protein-1 (bone morphogenetic protein-7) in the treatment of tibial nonunions. J Bone Joint Surg Am. 2001;83:S151-8.

7. Lou S, LV H, Li Z, Zhang L, Tang P. The effects of low-intensity pulsed ultrasound on fresh fracture: a meta-analysis. Medicine. 2017;96:e8181.

8. Leighton R, Watson JT, Giannoudis P, Papakostidis C, Harrison A, Steen RG. Healing of fracture nonunions treated with low-intensity pulsed ultrasound (LIPUS): a systematic review and meta-analysis. Injury. 2017; 48:1339-47

9. Jingushi S, Mizuno K, Matsushita T, Itoman M. Low-intensity pulsed ultrasound treatment for postoperative delayed union or nonunion of long bone fractures. J Orthop Sci. 2007;12:35-41.

10. Shi HF, Xiong J, Chen YX, Wang JF, Qiu XS, Wang YH, et al. Early application of pulsed electromagnetic field in the treatment of postoperative delayed union of long-bone fractures: a prospective randomized controlled study. BMC Musculoskelet Disord. 2013;14:35.

11. Boyette MY, Herrera-Soto JA. Treatment of delayed and nonunited fractures and osteotomies with pulsed electromagnetic field in children and adolescents. Orthopedics. 2012;35:e1051-5.

12. Assiotis A, Sachinis NP, Chalidis BE. Pulsed electromagnetic fields for the treatment of tibial delayed unions and nonunions. A prospective clinical study and review of the literature. J Orthop Surg Res. 2012;7:24.

13. Krishnakumar GS, Roffi A, Reale D, Kon E, Filardo G. Clinical application of bone morphogenetic proteins for bone healing: a systematic review. Int Orthop. 2017:41:1073-83.

14. von Rüden C, Morgenstern M, Friederichs J, Augat P, Hackl S, Woltmann A, et al. Comparative study suggests that human bone morphogenetic proteins have no influence on the outcome of operative treatment of aseptic clavicle non-unions. Int Orthop. 2016;40:2339-45.

15. von Rüden C, Morgenstern M, Hierholzer C, Hackl S, Gradinger FL, Woltmann $A$, et al. The missing effect of human recombinant bone morphogenetic proteins BMP-2 and BMP-7 in surgical treatment of aseptic forearm nonunion. Injury. 2016:47:919-24.

16. Starman JS, Bosse MJ, Cates CA, Norton HJ. Recombinant human bone morphogenetic protein-2 use in the off-label treatment of nonunions and acute fractures: a retrospective review. J Trauma Acute Care Surg. 2012;72:676-81.

17. Schandelmaier S, Kaushal A, Lytvyn L, Heels-Ansdell D, Siemieniuk RA Agoritsas T, et al. Low intensity pulsed ultrasound for bone healing: systematic review of randomized controlled trials. BMJ. 2017;356:j656.

18. Busse JW, Bhandari M, Einhorn TA, Schemitsch E, Heckman JD, Tornetta P, et al. Re-evaluation of low intensity pulsed ultrasound in treatment of tibial fractures (TRUST): randomized clinical trial. BMJ. 2016;355:15351.

19. Tarride JE, Hopkins RB, Blackhouse G, Burke N, Bhandari M, Johal H, et al. Low-intensity pulsed ultrasound for treatment of tibial fractures: an economic evaluation of the TRUST study. Bone Joint J. 2017;99:1526-32.

20. Hannemann PF, Essers BA, Schots JP, Dullaert K, Poeze M, Brink PR. Functional outcome and cost-effectiveness of pulsed electromagnetic fields in the treatment of acute scaphoid fractures: a cost-utility analysis. BMC Musculoskelet Disord. 2015;16:84.

21. Hannemann PF, Van Wezenbeek MR, Kolkman KA, Twiss EL, Berghmans $\mathrm{CH}$, Dirven PA, et al. CT scan-evaluated outcome of pulsed electromagnetic fields in the treatment of acute scaphoid fractures: a randomised, multicentre, double-blind, placebo-controlled trial. Bone Joint J. 2014;96:1070-6.

22. Hannemann PF, Mommers EH, Schots JP, Brink PR, Poeze M. The effects of low-intensity pulsed ultrasound and pulsed electromagnetic fields bone growth stimulation in acute fractures: a systematic review and meta-analysis of randomized controlled trials. Arch Orthop Trauma Surg. 2014;134:1093-106 
23. Hannemann PF, Göttgens KW, van Wely BJ, Kolkman KA, Werre AJ, Poeze M, et al. The clinical and radiological outcome of pulsed electromagnetic field treatment for acute scaphoid fractures: a randomised double-blind placebocontrolled multicentre trial. J Bone Joint Surg Br. 2012;94:1403-8.

24. Adie S, Harris IA, Naylor JM, Rae H, Dao A, Yong S, et al. Pulsed electromagnetic field stimulation for acute tibial shaft fractures: a multicenter, double-blind, randomized trial. J Bone Joint Surg Am. 2011;93: 1569-76.

25. Koga T, Niikura T, Lee SY, Okumachi E, Ueha T, Iwakura T, et al. Topical cutaneous $\mathrm{CO}_{2}$ application by means of a novel hydrogel accelerates fracture repair in rats. J Bone Joint Surg Am. 2014;96:2077-84.

26. Sakai Y, Miwa M, Oe K, Ueha T, Koh A, Niikura T, et al. A novel system for transcutaneous application of carbon dioxide causing an "artificial Bohr effect" in the human body. PLoS One. 2011;6:e24137.

27. Oe K, Ueha T, Sakai Y, Niikura T, Lee SY, Koh A, et al. The effect of transcutaneous application of carbon dioxide $\left(\mathrm{CO}_{2}\right)$ on skeletal muscle. Biochem Biophys Res Commun. 2011;407:148-52.

28. Akahane S, Sakai Y, Ueha T, Nishimoto H, Inoue M, Niikura T, et al. Transcutaneous carbon dioxide application accelerates muscle injury repair in rat models. Int Orthop. 2017;41:1007-15.

29. Ueha T, Oe K, Miwa M, Hasegawa T, Koh A, Nishimoto H, et al. Increase in carbon dioxide accelerates the performance of endurance exercise in rats. J Physiol Sci. 2018;68:463-70.

30. Ueha T, Kawamoto T, Onishi Y, Harada R, Minoda M, Toda M, et al. Optimization of antitumor treatment conditions for transcutaneous $\mathrm{CO}_{2}$ application: An in vivo study. Oncol Rep. 2017;37:3688-94.

31. Iwata E, Hasegawa T, Takeda D, Ueha T, Kawamoto T, Akisue T, et al. Transcutaneous carbon dioxide suppresses epithelial-mesenchymal transition in oral squamous cell carcinoma. Int J Oncol. 2016:48:1493-8.

32. Onishi $Y$, Kawamoto $T$, Ueha T, Kishimoto K, Hara H, Fukase $N$, et al. Transcutaneous application of carbon dioxide $\left(\mathrm{CO}_{2}\right)$ induces mitochondrial apoptosis in human malignant fibrous histiocytoma in vivo. PLoS One. 2012;7:e49189.

33. Takeda D, Hasegawa T, Ueha T, Imai Y, Sakakibara A, Minoda M, et al. Transcutaneous carbon dioxide induces mitochondrial apoptosis and suppresses metastasis of oral squamous cell carcinoma in vivo. PLoS One. 2014;9:e100530

34. Harada R, Kawamoto $T$, Ueha $T$, Minoda $M$, Toda M, Onishi $Y$, et al. Reoxygenation using a novel $\mathrm{CO}_{2}$ therapy decreases the metastatic potential of osteosarcoma cells. Exp Cell Res. 2013;319:1988-97.

35. Iwata E, Hasegawa T, Ueha T, Takeda D, Saito I, Kawamoto T, et al. Transcutaneous carbon dioxide enhances the antitumor effect of radiotherapy on oral squamous cell carcinoma. Oncol Rep. 2018;40:434-42.

36. Onishi $Y$, Akisue T, Kawamoto T, Ueha T, Hara H, Toda M, et al. Transcutaneous application of $\mathrm{CO}_{2}$ enhances the antitumor effect of radiation therapy in human malignant fibrous histiocytoma. Int J Oncol. 2014:45:732-8.

37. Takemori T, Kawamoto T, Ueha T, Toda M, Morishita M, Kamata E, Fukase N, et al. Transcutaneous carbon dioxide application suppresses bone destruction caused by breast cancer metastasis. Oncol Rep. 2018;40:2079-87.

38. Brinker MR, O'Connor DP. The biological basis for nonunions. JBJS Rev. 2016; 4(6). https://doi.org/10.2106/JBJS.RWW.15.00078.

39. Lu C, Miclau T, Hu D, Marcucio RS. Ischemia leads to delayed union during fracture healing: a mouse model. J Orthop Res. 2007;25:51-61.

40. Dickson K, Katzman S, Delgado E, Contreras D. Delayed unions and nonunions of open tibial fractures. Correlation with arteriography results. Clin Orthop Relat Res. 1994;302:189-93.

41. Santolini E, West R, Giannoudis PV. Risk factors for long bone fracture nonunion: a stratification approach based on the level of the existing scientific evidence. Injury. 2015;46:S8-19.

42. Giannoudis PV, Gudipati S, Harwood P, Kanakaris NK. Long bone non-unions treated with the diamond concept: a case series of 64 patients. Injury. 2015; 46:548-54.

43. Pountos I, Panteli M, Panagiotopoulos E, Jones E, Giannoudis PV. Can we enhance fracture vascularity: what is the evidence? Injury. 2014;45:S49-57.

44. Hankenson KD, Dishowitz M, Gray C, Schenker M. Angiogenesis in bone regeneration. Injury. 2011;42:556-61.

45. Augat $P$, von Rüden $C$. Evolution of fracture treatment with bone plates. Injury. 2018;49:S2-7.

46. Xue Z, Jiang C, Hu C, Qin H, Ding H, An Z. Effects of different surgical techniques on mid-distal humeral shaft vascularity: open reduction and internal fixation versus minimally invasive plate osteosynthesis. BMC Musculoskelet Disord. 2016;17:370.

47. Ronga M, Longo UG, Maffulli N. Minimally invasive locked plating of distal tibia fractures is safe and effective. Clin Orthop Relat Res. 2010;468:975-82.

48. Perren SM. Evolution of the internal fixation of long bone fractures. The scientific basis of biological internal fixation: choosing a new balance between stability and biology. J Bone Joint Surg Br. 2002;84:1093-110.

49. Farouk $O$, Krettek C, Miclau T, Schandelmaier P, Tscherne H. Effects of percutaneous and conventional plating techniques on the blood supply to the femur. Arch Orthop Trauma Surg. 1998;117:438-41.

\section{Publisher's Note}

Springer Nature remains neutral with regard to jurisdictional claims in published maps and institutional affiliations.
Ready to submit your research? Choose BMC and benefit from:

- fast, convenient online submission

- thorough peer review by experienced researchers in your field

- rapid publication on acceptance

- support for research data, including large and complex data types

- gold Open Access which fosters wider collaboration and increased citations

- maximum visibility for your research: over $100 \mathrm{M}$ website views per year

At BMC, research is always in progress.

Learn more biomedcentral.com/submissions 